\title{
Nomenclatural notes on Varronia (Boraginaceae s.l.) in Brazil
}

\author{
Notas nomenclaturales sobre Varronia (Boraginaceae s.l.) en Brasil
}

María Natividad Sánchez de Stapf ${ }^{1}$

\begin{abstract}
Typifications and new combinations are provided for Boraginaceae s.l. from Brazil in advance of the List of Species of the Brazilian Flora. Varronia leucomalla (Taub.) Borhidi is lectotypified, and is presented Varronia mayoi (Taroda) M. Stapf is presented as a new combination. Additionally, the identity of Varronia glandulosa (Fresen.) Borhidi and Varronia striata (Fresen.) Borhidi is discussed, and the names for these species are reestablished. Key words: Cordia, typification, new combination.

Resumen

Tipificaciones y nuevas combinaciones son provistas para Boraginaceae s.l. de Brasil como un avance de la lista para el Catálogo de la Flora del Brasil. Varronia leucomalla (Taub.) Borhidi es lectotipificada y la nueva combinación Varronia mayoi (Taroda) M. Stapf es presentada. Adicionalmente, la identidad de Varronia glandulosa (Fresen.) Borhidi y Varronia striata (Fresen.) Borhidi son discutidas y reestablecidos los nombres como válidos para estas especies.

Palabras claves: Cordia, tipificación, nueva combinación.
\end{abstract}

\section{Introduction}

Browne (1756) recognized Varronia for two species from Jamaica, and the genus was accepted and used by several early authors. However, the most modern authors have treated Varronia as a section or subgenus of Cordia L., although some such as Borhidi et al. (1988) recognized Cordia, Gerascanthus P. Browne, and Varronia P. Browne as different. Studies subsequent have not recognized Varronia at the generic level, and most have treated it as a section of Cordia (e.g., Johnston 1930; Taroda \& Gibbs 1986; Miller 1988; Estrada 1995). Recent efforts to examine generic limits within Boraginaceae (Gottschling et al. 2005; Miller \& Gottschling 2007) it has become evident that Varronia is sister to the rest of Cordia, and should be recognized at the generic level. Varronia comprises about 100 neotropical species of multistemmed shrubs with condensed inflorescences and evenly serrate leaves. There are about 30 species of Varronia in Brazil, which occur in a variety of habitats from forests, to "cerrado" and "caatinga" vegetation. The purpose of the present study is provided typifications and new combinations for Varronia from Brazil in advance of the List of Species of the Brazilian Flora. We also reestablished two species in Varronia.

\section{Material and Methods}

Most of the required combinations exist, either through the work of early authors, or from the recent nomenclatural review of Borhidi et al. (1988) and Miller (2007). However, the correct names from some taxa has not been clarified, including new combinations and typifications. This paper is based on the examination of the relevant taxonomic literature, and the study of herbaria materials in B, $\mathrm{BR}, \mathrm{CEPEC}, \mathrm{K}, \mathrm{M}, \mathrm{MO}, \mathrm{NY}$, and P. Protologues have always been compared with specimens.

\section{Results and Discussion}

Varronia leucomalla (Taub.) Borhidi is lectotypified, and a new combination, Varronia 
mayoi (Taroda) M. Stapf is presented. Also, Varronia glandulosa (Fresen.) Borhidi and Varronia striata (Fresen.) Borhidi are reestablished.

Varronia glandulosa (Fresen.) Borhidi, Acta Bot. Hung. 34(3-4): 391. 1988. Cordia glandulosa Fresen., in Mart., Eichl. \& Urban, Fl. bras. 8: 19. 1857. Lithocardium glandulosum (Fresen.) Kuntze, Revis. Gen. Pl. 2: 977. 1891. Type: BRAZIL. BAHIA: “in sepibus ad Villam Ilheos", XII, fl., C.F.P. Martius s.n. (holotype M!).

Johnston (1930) recognized Cordia glandulosa as synonym of $C$. multispicata Cham. based on characteristic of the leaves. According Johnston (1930), the material he saw it had the lower surface of the leaves denser and paler indumenta. He considered this pale form most striking variation, and supported the idea that it was not enough to be considered as different taxon. However, I revised this material, including Blanchet 877 , which also was checked by Johnston (1930). I agree with Fresenius when he described C. glandulosa as a new species due that its abundant glandular indumentum in the leaves and calyx external surface, which it not present in C. multispicata. This species is easily recognized by its axillary spicate inflorescences with the base of the peduncle adnate to the petiole, and the filiform calyx lobes, while $C$. glandulosa has the peduncle free, and the acute calyx lobes. Both species occur in Brazil, but the latter is restricted to northern Brazil. Therefore, we treat as belonging to two different species.

Varronia leucomalla (Taub.) Borhidi, Acta Bot. Hung. 34(3-4): 385. 1988. Cordia leucomalla Taub., Bot. Jahrb. Syst. 15(38): 14. 1893. Type: BRAZIL. RIO DE JANEIRO: Laranjeiras, 1871, fl., A.F.M. Glaziou 4146 (holotype B, destroyed; lectotype designated here P00634016!; isolectotypes K!, P00634015!,P00634017!)

Four specimens of Glaziou 4146 were found, one at $\mathrm{K}$, and three at $\mathrm{P}$. We select one of the duplicates deposited in $\mathrm{P}$ as lectotype, which it is closest agreement with the protologue.

Varronia leucomalla is distinctive and easily recognized from other Varronia species by the subglobose capitate inflorescences to shortly clavate, and the whitish, floccose hairs on the undersurface of the leaves and young stems. Varronia leucomalla is closely related to $V$. leucomalloides (Taroda) J.S. Mill. (=C. leucomalloides Taroda) sharing the lower surface of the leaves whitish-floccose, and stem and calyx with fine, whitish hairs. However, $V$. leucomalloides differs of $V$. leucomalla by its axillary inflorescences and smaller leaves (less than $5 \mathrm{~cm}$ ). Varronia leucomalla has terminal inflorescences and leaves more than $8 \mathrm{~cm}$. Both species are endemics to Brazil, however $V$. leucomalla is known only from Rio de Janeiro, and V. leucomalloides from Alagoas, Bahia, Ceara, and Paraíba states.

Varronia mayoi (Taroda) M. Stapf, comb. nov. Cordia mayoi Taroda, Notes Roy. Bot. Gard. Edinburgh 44: 129. 1986. Type: BRAZIL. BAHIA: "1.5 km de São Inácio sob rodovia a Gentio de Ouro", 24.II.1977, fl., R.M. Harley et al. 18983 (holotype CEPEC; isotypes $\mathrm{K}$ !, MO!, NY!, P!)

Cordia mayoi was described as a new species of Cordia subgen. Varronia by Taroda \& Gibbs (1986), which is characterized by its multistemmed shrubs with condensed inflorescences, and pollen grains 3-porates. Miller \& Gottchling (2007) reestablished Varronia genus to include all Cordia species with these morphological characters. Later, we examined the type material, and now we are proposing a new combination for this taxon.

Varronia mayoi is characterized by its ovate leaves, calyx with acuminate teeth, sericeous villosulous indumentum, and tubular-cylindrical corolla, ca. $12 \mathrm{~mm}$ long. Varronia mayoi is known only from Bahia, Brazil.

Varronia striata (Fresen.) Borhidi, Acta Bot. Hung. 34(3-4): 387. 1988. Cordia striata Fresen. in Mart., Eichl. \& Urban, Fl. bras. 8: 23. 1857. Lithocardium striatum (Fresen.) Kuntze, Revis. Gen. Pl. 2: 977. 1891. Type: BRAZIL. BAHIA: in silvis aphyllis (catingas) et in campis, Prince Maximilian s.n. (holotype M; isotype BR!).

Johnston (1930) said "I have seen no authentical material of Cordia striata", however he considered $C$. striata as synonym of $C$. leucocephala. The type specimens studied of the both species shown that V. striata can be recognized by its filiform calyx lobes and corolla between 1.8 to $2 \mathrm{~cm}$ long, whereas that $V$. leucocephala (Moric.) J.S. Mill. (= C. leucocephala Moric.) has acute calyx lobes and corolla larger, ca. $3 \mathrm{~cm}$ long.

\section{Acknowledgements}

I thank to Organization American States (OAS), the Secretaria Nacional de Ciencia y 
Tecnologia (SENACYT) of Panama, and Kew Latin American Research Fellowship Programme (KLARF) by the support. Also, I thank the curators of B, BR, CEPEC, K, M, MO, NY, and P herbaria for providing loans of specimens or access to collections. I am grateful to the anonymous reviewers for their valuable suggestions to improve the manuscript.

\section{References}

Borhidi, A.; Gondár, E. \& Orosz-Kovács, Z.S. 1988. The reconsideration of the genus Cordia L. Acta Botanica Hungarica. 34: 375-423.

Browne, P. 1756. The civil and natural history of Jamaica. London. 503p.

Estrada, S.J. 1995. Cordia subgénero Varronia (Boraginaceae). Flora de Colombia. Vol 14. Universidad Nacional de Colombia, Santafé de Bogotá. Pp. 1-174.

Gottschling, M.; Miller, J.S.; Weigend, M. \& Hilger, H.H. 2005. Congruence of a phylogeny of Cordiaceae
(Boraginales) inferred from ITS1 sequence data with morphology, ecology, and biogeography. Annals of the Missouri Botanical Garden 92: 425-437.

Johnston, I.M. 1930. Studies in the Boraginaceae, VIII. Observations on the species of Cordia and Tournefortia known from Brazil, Paraguay, Uruguay, and Argentina. Contributions from the Gray Herbarium of Harvard University 92: 3-89.

Miller, J.S. 1988. A revised treatment of Boraginaceae for Panama. Annals of the Missouri Botanical Garden 75: 456-521.

Miller, J.S. 2007. New Boraginales from Tropical America 5: New names and typifications for neotropical species of Cordia and Varronia. Novon 17: 372-375.

Miller, J. S. \& Gottschling, M. 2007. Generic classification in the Cordiaceae (Boraginales): Resurrection of the genus Varronia P. Br. (Cordiaceae). Taxon 56: 163-169.

Taroda, N. \& Gibbs, P.E. 1986. A revision of the Brazilian species of Cordia subgenus Varronia (Boraginaceae). Notes from the Royal Botanic Garden, Edinburgh 44: 105-140. 